\title{
VPLYV REDUKCIE VHODNOSTNÝCH KRIVIEK NA VHODNOSŤ TOKU
}

\author{
INFLUENCE OF REDUCTION OF HABITAT SUITABILITY CURVES ON \\ AQUATIC HABITAT SUITABILITY
}

Gréta Doláková* $^{*}$, Viliam Macura $^{1}$, Andrej Škrinár $^{1}$, Milan Čistý ${ }^{1}$

"greta.dolakova@stuba.sk

' Stavebná fakulta STU v Bratislave , Katedra vodného hospodárstva krajiny, Radlinského 11, 81005 Bratislava

\begin{abstract}
Abstrakt
Doterajší výskum akvatického monitoringu rybích preferencií v mikrohabitatoch slovenských riek obsahuje podrobné hydromorfologické, topografické a ichtyologické merania vhodné na komplexnú analýzu. Následné hydrologické modelovanie tejto databázy porovnáva biotické parametre, reprezentované vhodnostnými krivkami, $\mathrm{s}$ abiotickými parametrami tokov, za ciel'om zistit' preferencie rýb v mikrohabitatoch. Výskum pojednáva o opodstatnení vplyvu následnej redukcie vhodnostných kriviek na vhodnost' akvatického habitatu, pre zlepšenie metodiky hodnotenia biotopov pomocou regresného modelu. Výskum vytvára optimálny regresný vzt’ah na určenie miery redukcie kriviek vhodnosti habitatov na horských a podhorských tokoch na Slovensku.
\end{abstract}

\section{Kl’účové slová}

Vhodnostné krivky, hydrologické modelovanie, IFIM, akvatický habitat, regresný model

\begin{abstract}
Previous research into the aquatic monitoring of microhabitat fish preferences in Slovakia contains detailed valuable hydro-morphological, topographic, and ichthyological measurements for complex analysis. Consequent hydrological modeling of the database compares biotic parameters, represented by habitat suitability curves, and abiotic parameters of streams, to investigate the fish preferences of aquatic microhabitats. The research discusses an option if subsequent influence of reduction of habitat suitability curves on aquatic habitat suitability is justified to improve methodology of habitat assessment by regression model. The research creates an optimal regression relationship to determine the degree of habitat suitability curves reduction on mountain and piedmont streams in Slovakia.
\end{abstract}

Key words

Habitat suitability curves, hydrological modeling, IFIM, aquatic habitat, regression model

\section{1 ÚVOD}

Zmena životného prostredia spôsobená antropogénnym vplyvom za posledné storočie výrazne zmenila režim prúdenia a prirodzený vzhl'ad a funkciu riek na výrazne zmenené vodné útvary (heavily modified water bodies) [1], [2], [3], [4]. V dôsledku toho je celosvetový stav všetkých vodných ekosystémov zretel'ne horší ako v iných ekosystémoch [5]. Akvatický habitat toku v období minimálneho prietoku môže byt' rozdelený na dva funkčné celky. Prvým celkom sú mikrohabitaty, ktoré majú funkciu poskytnút' priaznivé podmienky pre ryby v období minimálneho prietoku. Tieto habitaty sú reprezentované rôznymi útvarmi ako sú napríklad výmole a tône, ktoré sú predovšetkým charakterizované väčšou híbku toku, tento priestor sa nazýva úkryt. Druhým celkom je zvyšná čast' toku, ktorá má menšiu híbku toku a preto neposkytuje vhodné podmienky pre dlhodobý pobyt rýb, ale nebráni ich migrácii. Tento priestor sa nazýva vol’ná hladina. S týmto základným rozdelením pracuje teória na vývin metodiky hodnotenia kvality ekologického potenciálu pomocou regresných modelov. 


\section{POPIS SÚČASNÉHO STAVU}

Vodné útvary a predovšetkým riečne systémy zasiahli vel'koplošné úpravy s hlavným zámerom len protipovodňovej ochrany a teda zvýšsenie kapacity riečneho koryta, čo malo za následok zníženie geomorfologickej členitosti koryta [6]. Úspešne prevedené revitalizácie na celom svete naznačujú, že vylepšenie členitosti hydromorfológie koryta toku má výrazne pozitívny vplyv na ekologický systém akvatického habitatu a preferencie rybích spoločenstiev osídl'ovat' takýto habitat. Na Slovensku prebieha výskum monitorovania preferencií rýb na osídlenie mikrohabitatov od roku 1995 [7] a je založený na podrobných ichtyologických, hydrometrických a topografických meraniach [8]. Požiadavku kvalitnej metodiky na hodnotenie a zaradenie vodných útvarov predpisuje aj Rámcová smernica vody 2000/60/ES a za týmto účelom sa v rôznych projektoch prevádzajú odlišné skupiny hodnotení vodných útvarov. Hodnotenie sa prevádza v častiach biologické prvky kvality, fyzikálno-chemické prvky kvality, špecifické látky a hydromorfologické prvky kvality.

Táto štúdia sa zameriava na hodnotenie a zaradenie vodných útvarov na základe hydromorfologických prvkov horských a podhorských tokov. Podobným typom vyhodnocovania kvality tokov a zaradenia do kategórii pomocou algoritmov sa doposial' v minulosti nikto nezaoberal.

\section{Bioindikátor}

Pre slovenské podmienky sa prejavuje ako najvhodnejší bioindikátor kvality habitatu pstruh potočný (Salmo trutta $\mathrm{m}$. fario). Je tomu tak hlavne kvôli jeho vysokej senzitivite na zmeny v členitosti koryta, častému výskytu a najvyššej korelácií vhodnostných kriviek [9], [10]. Vplyv geologického podložia na preferencie výskytu rýb dokázaný nebol [7], čo naznačuje, že zmeny v dostupnosti habitatu sú nelineárne a nie úplne jednoznačné. Hlavným parametrom pre pstruha potočného je počas nízkych prietokov, v slovenských podhorských a horských tokoch, parameter híbky vody. No naopak v povodňovej perióde, s vyššími prietokmi, sa môže táto konektivita na híbku menit' a parameter rýchlosti môže dosiahnut' dôležitejšiu funkciu v preferenciách rybích spoločenstiev na vhodnejší mikrohabitat. Všetky terénne merania boli prevedené počas letných minimálnych prietokov, ktoré pôsobia pre akvatický habitat ako stresový faktor, častokrát obmedzujúci ich populáciu. Minimálne prietoky majú značný negatívny vplyv na akvatický habitat toku. Je tomu tak kvôli nízkej híbke vodného stípca a nízkemu obsahu rozpustného kyslíka, ktoré obmedzujú možnosti úkrytov pre ryby.

\section{METODIKA}

Pre stanovenie vplyvu redukcie vhodnostných kriviek z pohl’adu parametra híbky na kvalitu akvatického habitatu tokov bola vybratá nasledujúca metodika:

- určenie referenčných prírodných úsekov tokov,

- hydrometrické a topografické terénne meranie úsekov tokov,

- ichtyologický prieskum úsekov tokov,

- $\quad$ zvolenie bioindikátora, generalizácia vhodnostných kriviek

- vplyv charakteristík habitatu na plochu - Area Weighted Suitability (AWS),

- korelačná a regresná analýza redukcie charakteristík toku a ich vplyv na kvalitu akvatického habitatu,

- korelačná a regresná analýza vhodnostných kriviek z pohl’adu parametra hĺbky na kvalitu habitatu.

Úseky boli vyhodnocované z najmä z hl'adiska parametra híbky, ale s ohl'adom na celkovú hydromorfologickú stavbu úseku. Výstup vo forme Váženej využitel'nej plochy (AWS) predstavuje kodependenciu hydromorfologického vzhl'adu toku, prúdenia a biotického faktora, v tomto prípade ryby, pstruha potočného.

Z pohl'adu ekologického potenciálu akvatického habitatu riek sú dôležité mikrohabitaty typu úkryt. Preto pre určenie AWS je potrebné definovat' jednotlivé parametre týchto úkrytov. Ako už bolo spomenuté, v období letných prietokov je rozhodujúca híbka toku, z tohoto dôvodu je kvalita habitatu odvodená z híbky toku, ktorej zodpovedá miera vhodnosti odčítaná z vhodnostnej krivky pre danú hĺbku AWS. Túto hodnotu nazývame parameter hĺbky, ako výsledok hydrologického modelovania Combined Suitability Index (CSI), ktorého hodnota sa vyjadruje $\mathrm{v}$ intervale $(0-1)$. K určeniu vplyvu priemernej CSI na charakterizáciu úkrytu bola zrealizovaná regresná analýza pre redukciu miery vhodnosti od 0,1 po 1 . Analýza bola realizovaná na celkovej databáze 58 úsekov. Č́m je obmedzenie výsledkov CSI vyššie, tým je plocha vhodného habitatu menšia, čo sa logicky premietne v znížení celkových hodnôt AWS za úsek toku. Výsledky regresnej analýzy boli vyhodnotené cez štatistické parametre RMSE (Root Means Square Error), R a PBIAS (priemerná percentuálna odchýlka - kladná hodnota model nadhodnocuje, záporná podhodnocuje, 0 predstavuje ideálnu hodnotu). 


\section{VÝSLEDKY}

Z výsledkov vyplýva, že najvyšší korelačný koeficient $\mathrm{R}$ je pri hodnote $C S I=0,3, R=0,904$, najnižšiu hodnotu RMSE $=0,059$ a jednu z najvyhovujúcejších hodnôt PBIAS $=-2$. Na základe týchto výsledkov analýzy bola prepočítaná hodnota AWS pre celý úsek daného toku.

Na základe tejto regresnej analýzy boli prepočítané AWS pre tri hodnoty redukcie $\emptyset$ CSI 0,3-0,5. Výsledky boli porovnané s neupravenými pôvodnými hodnotami AWS a aj s hodnotami AWS odvodených z d’alšej rovnice regresnej analýzy modelom LASSO.

Least Absolute Selection And Shrinkage Operator (model LASSO) bola použitá ako lineárna regulovaná regresia. Pri hl’adaní najvhodnejšieho regresného vzt’ahu medzi parametrami sa použila tzv. interakcia premenných. Čo predstavovali vzájomné interakcie $\mathrm{v}$ najvyššom počte 2 premenných, ktorých vzájomné spolupôsobenie je vyjadrené ich súčinom. Vstupné dáta do regresnej analýzy boli rozdelené na tvorbu regresného modelu, kalibračné a testovacie.

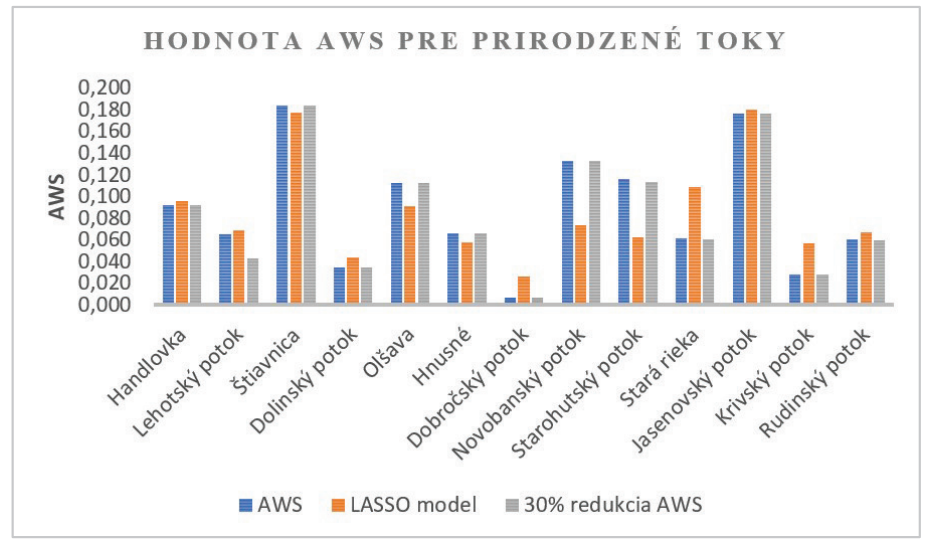

Obr. 1 Porovnanie hodnoty AWS pre prirodzené toky.

\section{DISKUSIA}

Hodnoty AWS vypočítané z d’alšej regresnej rovnice na základe LASSO modelu sú charakterizované mierne vyššími rozdielmi $(\mathrm{R} 2=0,703)$, avšak stále zachovávajú rovnaký trend dát. Toto je možné zdôvodnit' tvorbou samotnej regresie, ktorá dáta trénuje na referenčných úsekoch a v konečnom výsledku ich sploštuje. $Z$ výsledkov vyplýva, že redukcia CSI $=30 \%$ má nepodstatný vplyv na AWS. Uvedený výsledok je možné vyložit samotným spôsobom zberu dát, ktoré samotnú redukciu zohladňuje už pri identifikácii rybích úkrytov. Do datasetu tak vstupujú už len mikrohabitaty s väčšou híbkou vody, čomu zodpovedá aj vyššia hodnota CSI. Z uvedeného výskumu vyplýva, že nie je potrebná žiadna následná matematická redukcia vhodnostných kriviek na základe CSI pri vyhodnocovaní dát a metodika manuálneho zberu dát bola týmto spôsobom overená.

\section{ZÁVER}

Hlavným parametrom vhodnosti akvatického habitatu pre rybie spoločenstvá je počas nízkych prietokov parameter híbky vody a na to priamo nadväzujúca existencia úkrytov a rôznorodá členitost’ priečneho a pozdížneho profilu toku. Dokazujú to vyššie hodnoty AWS v prirodzených úsekoch tokov, kde je táto členitost' stále prirodzená a zachovaná. Takáto prítomnost' členitého prostredia a úkrytov priamo vplýva na osídlenie toku rybami. Pokial' sa členitost' upraví regulovaním tokov, je vel'mi pravdepodobné, že pre ryby nezostáva minimálny prietok pre ich prežitie aj v kritickom letnom období. Hodnotenie kvality a ekologického potenciálu toku sa však vykonáva holisticky z pohl’adu rôznych kategórii, v princípoch, ktoré zohl’adňuje samotná vedná disciplína ekohydrauliky.

Účelom tohoto výskumu bola produkcia metodológie na stanovenie miery antropogenického vplyvu na horské a podhorské slovenské toky z pohladu hydromorfologických prvkov kvality. Mieru vplyvu v tomto prípade reprezentuje výsledok z hydrologického modelovania AWS. Tento výstup sa následne určil aj z regresnej rovnice. Oba výstupy bolo potom možné porovnat's redukovanou hodnotou CSI, ako overenie matematického kroku 
v postupnosti metodológie. Metodológia bola utvorená na základe základných hydromorfologických parametrov toku, meratel'ných v rámci terénneho zberu dát, iba s použitím jednoduchého zariadenia, pásma a ciachovanej tyči na meranie híbky toku. Z prevedenej regresnej analýzy dát vyplýva, že nie je potrebná žiadna následná matematická redukcia vhodnostných kriviek na základe CSI a metodika manuálneho zberu dát jednoduchým vybavením bola týmto spôsobom overená.

\section{Pod'akovanie}

Článok vznikol vd’aka podpore projektov VEGA 1/0068/19 a APVV-16-0253.

\section{Použité zdroje}

[1] M. Delibas and A. Tezer, “'Stream Daylighting' as an approach for the renaturalization of riverine systems in urban areas: Istanbul-Ayamama Stream case,” Ecohydrology and Hydrobiology, vol. 17, no. 1, pp. 18-32, Jan. 2017, doi: 10.1016/j.ecohyd.2016.12.007.

[2] M. E. J. Cutler, D. S. Boyd, G. M. Foody, and A. Vetrivel, "Estimating tropical forest biomass with a combination of SAR image texture and Landsat TM data: An assessment of predictions between regions," ISPRS Journal of Photogrammetry and Remote Sensing, vol. 70, pp. 66-77, Jun. 2012, doi: 10.1016/j.isprsjprs.2012.03.011.

[3] Z. A. Latif, I. Zamri, and H. Omar, "Determination of tree species using Worldview-2 data," in Proceedings - 2012 IEEE 8th International Colloquium on Signal Processing and Its Applications, CSPA 2012, 2012, pp. 383-387. doi: 10.1109/CSPA.2012.6194754.

[4] Q. Guo, X. Liu, X. Ao, J. Qin, X. Wu, and S. Ouyang, "Fish diversity in the middle and lower reaches of the Ganjiang River of China: Threats and conservation," PLOS ONE, vol. 13, no. 11, p. e0205116, Nov. 2018, doi: 10.1371/journal.pone.0205116.

[5] C. Revenga, J. Brunner, N. Henninger, K. Kassem, and R. Payne, "Pilot analysis of global ecosystems: freshwater systems.," Pilot analysis of global ecosystems: freshwater systems., vol. 2001305512, no. 1569734607, 2000.

[6] Z. Štefunková, A. Škrinár, I. Belčáková, P. Halaj, and P. Ivan, "Determination of the Qualitative Features of Watercourses for Restoration in the Urban Environment," Procedia Engineering, vol. 161, pp. 2329, 2016, doi: 10.1016/j.proeng.2016.08.492.

[7] V. Macura, A. Škrinár, K. Kaluz, M. Jalčovíková, and M. Škrovinová, "Influence Of The Morphological And Hydraulic Characteristics Of Mountain Streams On Fish Habitat Suitability Curves," River Research and Applications, vol. 28, no. 8, pp. 1161-1178, Oct. 2012, doi: 10.1002/rra.1518.

[8] I. Stankoci, J. Jariabková, and V. Macura, "Evaulation of the Quality of an Aquatic Habitat on the Drietomica River,” Slovak Journal of Civil Engineering, vol. 22, no. 1, pp. 43-48, Mar. 2014, doi: 10.2478/sjce-2014-0006.

[9] Z. Štefunková et al., "The Impact of The Morphology of Mountain Watercourses on The Habitat Preferences Indicated by Ichtyofauna Using the IFIM Methodology,” Applied Ecology and Environmental Research, vol. 16, no. 5, pp. 5893-5907, 2018, doi: 10.15666/aeer/1605 58935907.

[10] Z. Štefunková et al., "Relationship between Morphological Characteristics and Quality of Aquatic Habitat in Mountain Streams of Slovakia," Water 2021, Vol. 13, Page 142, vol. 13, no. 2, p. 142, Jan. 2021, doi: 10.3390/W13020142. 